\title{
reviews
}

Is research management really as boring as this book makes it sound? "Finally he should desirably exercise some flair which stamps his department with an identity, making it recognisable as a unit with a reputation for excellence", writes $\mathrm{Mr}$ White at the end of less than a page devoted to the attributes of a research leader. Flair is the ingredient conspicuously missing from what is really a rather expensive handbook of information for the research manager, long on lists of research laboratories but very short on convincing examples of either successful or mismanaged research.

Never has there been a greater need than now for a book on the effective management of an inherently labourintensive activity. Never has there been greater need for advice on how to make maximum use of scientific talent, by example and inspiration, and by providing scientists with efficient tools and support. Yet I looked in vain for specific examples of people who have succeeded in making better use of a scientist's time, or examples of balanced (and unbalanced) research portfolios. Where, at a time when those responsible for granting or rejecting applications for research funds are so well aware that funds are flowing not to the most deserving areas of research but to scientists who can write a convincing proposal, is advice on how to put forward your case for research? What are the differences between a good and a bad research proposal? To be more chari-

\section{Competent if not inspired}

\section{David Fishlock}

Effective Management of Research and Development. By P. A. F. White. Pp. $\mathrm{x}+295$. (Macmillan: London and Basingstoke, May 1975.) $£ 10.00$.

table, the author's most recent experience of research management, as a divisional head at the atomic weapons factory at Aldermaston, one of the most secret enclaves of science in Britain, has probably had an inhibiting effect on his readiness to supply or seek out the kind of details and examples that could have enlivened his book so much. But it scarcely excuses him from the charge of publishing out-of-date information. The long lists of research laboratories in Britain, given presumably to help the research manager with a problem to select a contractor who might help, contain names that no longer exist, and record budgets of four or five years ago, even for a public corporation such as the National Research and Development Council whose annual reports are readily available. One table offering the ratio of research funds spent in-house to those subcontracted, for 11 industries, is dated 1966-67.
SINCE the previous volume in this series the stated theme. Reviews which are of symposia devoted to virology was not so confined include the first three published in 1968 progress in the field has been considerable. This compilation of 14 articles on the theme of control processes in virus multiplication is, therefore, an invaluable source of information for students and would-be students of animal virology.

Like other symposia in the series this is a collection of specially written review articles, rather than research papers, aimed at a readership of general microbiologists. This symposium deals principally with animal viruses. Only 4 of the 14 articles are concerned specifically with bacteriophages, and none of them considers the multiplication of plant viruses though there is a mention of certain structural aspects of these in an article by Showe and Kellenberger.

The editors have to a large extent succeeded in keeping the articles within which are intended to provide back-

\section{Latest virology}

Control Processes in Virus Multiplication. (25th Symposium of the Society for General Microbiology, London, April 1975.) Edited by D. C. Burke and W. C. Russell. Pp. viii +449 . (Cambridge University Press: London, New York and Melbourne, 1975.) £9.00; $\$ 27.50$.

ground information to the subsequent reviews. Indeed, Dressler in a very readable article admits that very little is known about the control of DNA art' at the time of writing, and if the replication but explains the advantages reader is more impressed on occasions available to DNA molecules which by our lack of knowledge, then we trust adopt a circular form for replication, he or she may be stimulated to repair and goes on to describe the way the the deficiency!" A. C. R. Samson
T7 bacteriophage genome replicates without adopting a circular form.

Some of the articles are not easily assimilated perhaps because they each deal with a different aspect (or closely related aspects) of control for all the main classes of animal virus; they may have been easier to assimilate if each had dealt with a different class of viruses but had explored all aspects of control known within that class.

I strongly recommend this comprehensive collection of authoritative review articles on a theme of great significance in the field of virology, and will conclude with a quotation from the editors' preface: " . . . it has been our intention to describe the 'state of the rt' at the time of writing, and if 'the
When, however, the author drops the pretence of providing a handbook of up-to-date research data and concentrates on writing a textbook of research management, he stands on firmer ground. The latter half of his book starts with a chapter on the choice of a research and development portfolio"probably the most important task of research management"-in which he sets out the principles, basically three, and reviews the sophisticated techniques which nowadays can help the manager to calculate economic benefit. Here I would cavil only at the brevity of the section on the stopping of research projects, acknowledged to be "one of the most difficult of a director's activities" yet commanding less than four pages when a whole chapter would have been fully justified. But it leads into further chapters on the control of projects, on efficiency and productivity in research and development, and on choosing research staff.

At the end of each chapter the author provides a brief but lucid summary of the points he has been trying to make. Rereading this review I think that the point I really want to make is that $\mathrm{Mr}$ White has almost totally neglected the human factor in an activity where, perhaps more than in any other field of endeavour, the difference in terms of success between competent and inspired research management-as between competent and inspired research-is a very big factor indeed. 